\title{
FIRST RECORD OF PLAGIOBRISSUS COSTAI (GASCO, 1867) (ECHINOIDEA, BRISSIDAE) IN THE ADRIATIC SEA
}

\author{
Pamela Budicin \\ Srednja škola Zvane Črnje Rovinj, Carduccijeva ulica 20, HR-52210 Rovinj, Croatia \\ (e-mail: pamela.budicin@gmail.com)
}

Budicin, P.: First record of Plagiobrissus costai (Gasco, 1867) (Echinoidea, Brissidae) in the Adriatic Sea. Nat. Croat., Vol. 28, No. 2., Zagreb, 2019.

The finding of an irregular sea urchin test in Mljet Channel near Pelješac Peninsula has provided first information on the presence of the rare endobenthic Plagiobrissus costai in the Eastern Adriatic. With this species, in the last 270 years, ten irregular echinoderm species have been recorded in the Adriatic Sea.

Key words: Echinoidea Irregularia, Brissidae, Plagiobrissus costai, Adriatic Sea, Croatia

Budicin, P.: Prvi nalaz Plagiobrissus costai (Gasco, 1867) (Echinoidea, Brissidae) u Jadranu. Nat. Croat., Vol. 28, No. 2. Zagreb, 2019.

Nalazom prazne ljušture iregularnog ježinca u Mljetskom kanalu kod poluotoka Pelješca utvrđena je prisutnost rijetke vrste pjeskovitog dna Plagiobrissus costai u istočnom dijelu Jadranskog mora. Nakon ovog nalaza u proteklih 270 godina do danas u Jadranu je zabilježeno ukupno deset vrsta iregularnih ježinaca.

Ključne riječi: iregularni ježinci, Brissidae, Plagiobrissus costai, Adriatic Sea, Croatia

\section{INTRODUCTION}

Since the classic biological research by Donati (1750) and Olivi (1792), nine irregular sea urchins have been recorded in the Adriatic Sea (Despalatović et al., 2017). They were reviewed by Heller (1868), Carus (1895), Kolosváry (1937), Zavodnik (1961), Tortonese (1965), Bruno (1972), Fredj (1974), Vidović Matvejev (1978), KašćElan et al. (2009), Matarrese (2010), and in reports of museum and study collections (Tortonese, 1935, 1956, 1977, 1984; MarcuzZi, 1972; ZavodniK et al., 2001). In coastal areas the material was mostly collected in fishermen's gear, sometimes by snorkeling and sophisticated scientific equipment, and more recently in scuba diving adventures. Consequently, the Eastern Adriatic echinoid fauna seems to be at first sight a well known systematic group of benthic macrofauna, although published documented records of species like the Brissidae group are relatively poor in the Central and Southern Adriatic (Fig. 1). Therefore, the record of new species appeared unlikely, apart from invaders from other parts of the Mediterranean.

In 2017 a team of amateur scuba divers undertook an excursion to survey the wreck of the German Navy torpedo boat named S 57 (FrKa \& Mesić, 2003; Andrić, 2012). It was set on fire and sunk in a night battle with British ships on 19 August 


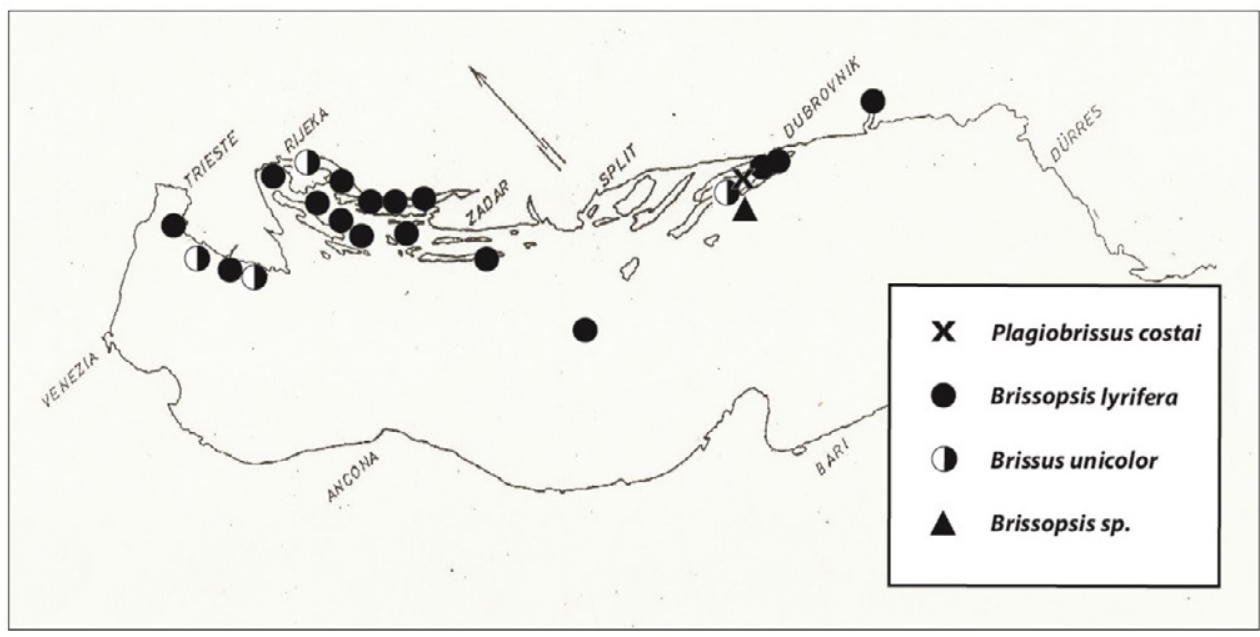

Fig. 1. Record sites of Brissidae species in the Eastern Adriatic, areas of Slovenia, Croatia, Montenegro and Albania (Kolosváry, 1938, 1940; ZAVodniK, 1971, 1992, 1996, 1998, 2003; Bruno, 1972; Tortonese, 1984; Zavodnik \& Kovačíć, 2000; ZavodniK et al., 2006; KašćElan et al., 2009).

1944 in Mljet Island Channel. The wreck lies on gently sloping barren rough sandy bottom void of any kind of marine vegetation. While diving the author accidentaly saw and collected some tests of irregular echinoids, and among them there was one test of a species so far never found in Eastern Adriatic. The present paper is a detailed report on this finding.

\section{MATERIAL AND METHODS}

In Mljet Island Channel in the vicinity of the coastal cliffs of the Pelješac peninsula, at GPS: $42^{\circ} 51^{\prime} 21^{\prime \prime} \mathrm{N}, 17^{\circ} 29^{\prime} 37^{\prime \prime}$ E, UTM XH33, near the wreck of the German Navy torpedo boat one test of irregular Echinoidea from the Brisseidae group was collected by author by hand from the surface of the rough sand slope at a depth of 26-38 m (Fig. 2). It was filled with sandy sediment, void of pedicelariae and spines, and slightly damaged in the anal area (Fig. 3). The sediment was easily removed through the oral aperture and the anal area was lacking in plates. No teratological features similar to those reported in Brissopsis lyrifera by BRATTSTRÖM (1946) were observed. The test was not infested by fouling organisms. Due to lack of time the benthic community in the sandy area around the torpedo-boat S 57 wreck was not analyzed in detail. However, on the areal sediment surface a lot of Echinocardium sp. and Spatangus purpureus tests were observed. Adults of these species normally inhabit rough sands, shallowly hidden in the ground. It seems therefore that at the locality surveyed there is a community of rough sands under bottom currents (SGCF) (Pérès \& Picard, 1964; Strenger, 1970; Pérès \& GamulinBrida, 1973; Massé, 1994; Bakran-Petricioli, 2011). It should be added that the fouling community settled on the metal construction of the wreck was similar to occurrence on numerous vessels sunken in the shallow coastal areas of the eastern Adriatic. 


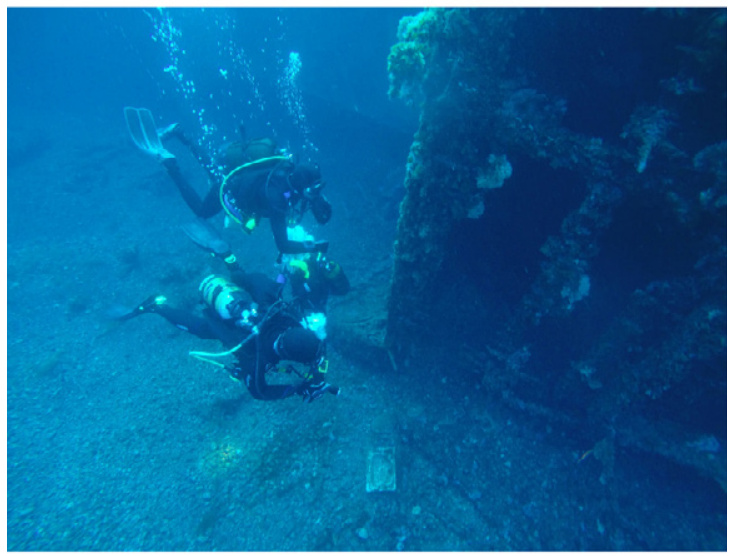

Fig. 2. Community of rough sand under bottom current next to the wreck of the torpedo boat $S 57$. Depth: 26-38 m (photo P. Budicin).
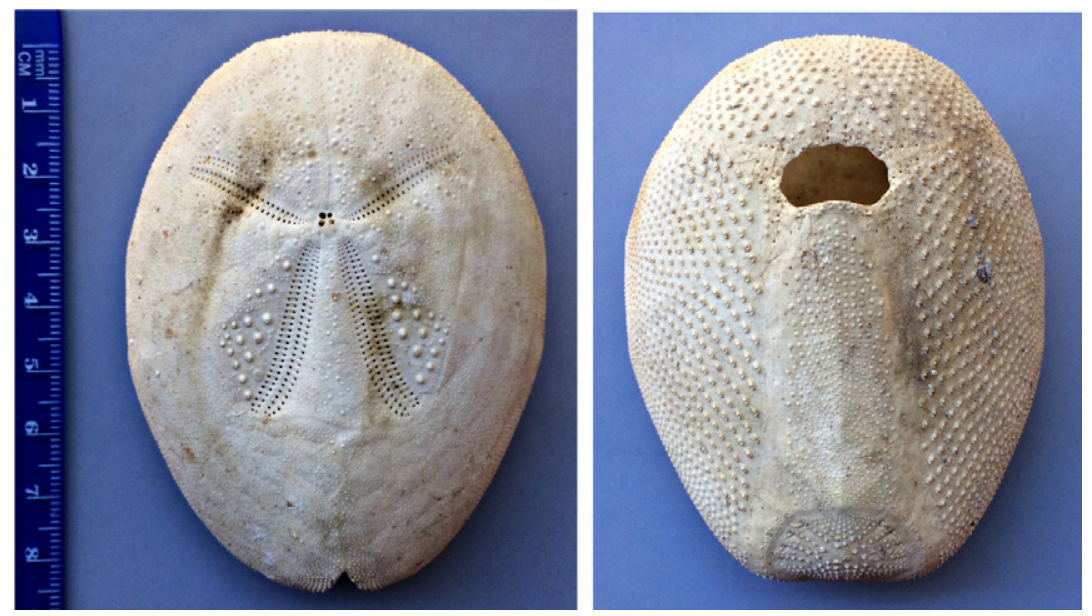

Fig. 3. Plagiobrissus costai (Gasco, 1867) test from Mljet Chanel. Left: dorsal (aboral) side. Right: ventral (oral) side (photo P. Budicin).

The morphology, size, location and number of primary tubercles of our test were applied by identification of the irregular urchin tests (KoEHLER, 1927; Tortonese, 1965). Dr. Dušan Zavodnik confirmed the species identification. The voucher specimen is kept in a private collection.

\section{RESULTS AND DISCUSSION}

The dimensions of the collected test are: length $76 \mathrm{~mm}$, width $64 \mathrm{~mm}$, and height $38 \mathrm{~mm}$ (Fig. 3). Peripetal fasciole is slightly asymmetrical, $57 \mathrm{~mm}$ long. Anal fasciole is damaged. Large spine tubercles inside peripetal fasciole are 17 in the left side of the test, and 18 in the right side. The dried test colour is dirty white. It is rather frail, similar to loveniid sea urchins. According to the outer morphology 
of the test surface and in comparison with similar irregular sea urchins (KoEHLER, 1927; Mortensen, 1951; Tortonese, 1965) this specimen has been identified as Plagiobrissus (Rhabdobrissus) costae (Gasco, 1876).

Plagiobrissus costai is a typical endobenthic irregular sea urchin (Echinodermata: Echinoidea: Clypeasteroida: Brissidae). In general, adult irregulars inhabit coastal and offshore sandy and silty sediments, burrowing in the ground from a few to forty and more centimetres deep (Tortonese, 1965; Garcia Raso et al., 1992; ZAvoDNIK, 1992). Exact depth of the sediment layer suitable for adult individuals in most of the Adriatic Sea irregular echinoids is not known. It seems that Clypeasteroid behaviour habits are the main reason for the rather rare capture records of live specimens worldwide. On the other hand, tests lacking in spines and pedicellariae occasionally were collected by means of bottom trawls and grabs. At present by far the most efficient collection of echinoid tests visible on sediment surface is by autonomic (scuba) divers.

Endobenthic irregular echinoids (Clypeasteroida) are well distributed in European seas (VAsseur \& CARLSEN, 1948; HAnsson, 2001). Until the present, the Adriatic Sea records of clypeasteroids consisted of total of 9 species pertaining to the families Fibulariidae (Echinocyamus pusillus), Spatangidae (Spatangus purpureus), Schizasteridae (Schizaster canaliferus), Loveniidae (Echinocardium cordatum, E. fenauxi, E. mortenseni), and Brissidae (Brissopsis lyrifera, Brissopsis cf. atlantica mediterranea Mortensen, 1913 and Brissus unicolor. Some species are well distributed elsewhere in the Mediterranean and Adriatic Sea, especially Echinocyamus pusillus, Spatangus purpureus, Schizaster canaliferus, and Brissopsis lyrifera (Tortonese, 1935; 1965; ZavodniK, 1992; Kašćelan et al., 2009; Dhora, 2010; Matarrese, 2010; Bakran-Petricioli, 2011).

Now we can add Plagiobrissus costai to the Adriatic list of irregular echinooids. In the Mediterranean, outside the Adriatic Sea it was recorded in Tyrrhenian Sea of Capri Islands (locus typicus by Gasco (1876), and Koehler (1927) under the name Metalia costae; Tortonese, 1965), at Taranto (Ionian Sea, by Tortonese, 1961, 1977), in Haifa Bay (Levantine area, Tortonese, 1957), at Ischia, Stromboli and Genoa in Italian coastal waters (Tortonese, 1977; Matarrese, 2010), and the Balearic Islands in the Western Mediterranean (Koenler, 1927; Tortonese, 1965; Fredj, 1974). Specimens of Plagiobrissus were collected on sandy bottom, somewhere within sea grass associations (PAstorino \& CANU, 1965), at 5-75 m depth (Tortonese, 1977). It is the only species of this genus recorded in European seas (Koehler, 1927; Hansson, 2001).

The specimen test we have studied apparently is rather fragile and its condition suggests that it was not exposed to fast bottom currents. The absence of fouling organisms settled on the test surface, like the bryozoan colonies and sedentary polychaetes on the shells of the big fan mussel Pinna nobilis (ZAvodniK, 1963; LegAC, 2012), on radioles of cidaroid echinoids (TORTONESE, 1965), and on tests of the irregular sea urchin Spatangus purpureus (ZAvodNIK \& ŠImUNović, 1997) suggest that the exposure period of our Plagiobrissus test to a free water environment was not long.

The biology and test variations in some common irregular sea urchins, such as in Echinocyamus pusillus, Spatangus purpureus, some Echinocardium species, Schizaster canaliferus, and Brissopsis lyrifera are rather well known (BRATTSTRÖm, 
1946; VAsseur \& CARlsen, 1948; Tortonese, 1965). On the other hand, in the rather rare Plagiobrissus costai reports, no information is available on its test and spine variability, the behaviour and population density, or on the ecological significance of this endobenthic species. Therefore, from the zoogeographical point of view an important question appeared: does this species belong to a steady Adriatic indigenous population, or is it perhaps a recent immigrant from other parts of the Mediterranean Sea?

\section{ACKNOWLEDGEMENTS}

Sincere thanks to diving colleagues who accompanied and helped me in the visit to the boat S 57 wreck. I am much obliged to Dr. Nikola Tvrtković, Marijana Vuković, Erika Folo, and the anonymous referees for valuable suggestions as to how to improve the manuscript. And naturally, most cordial thanks to my grandfather Mr Dušan Zavodnik who taught me to love Nature, encouraged my professional duties, and took care of my diving adventures.

Received September 18, 2018

\section{REFERENCES}

Andrić, M., 2012: Ronjenje u Hrvatskoj. Sve tajne Jadranskog podmorja. EPH Media d.o.o., Zagreb, $249 \mathrm{pp}$.

Bakran-Petricioli, T., 2011: Priručnik za određivanje morskih staništa u Hrvatskoj prema direktivi o staništima EU. Državni zavod za zaštitu prirode, Zagreb, 184 pp.

Brattström, H., 1946: Observations on Brissopsis lyrifera (Forbes) in the Gullmar Fjord. Ark. Zool. 37 A (18), 1-27.

Bruno, C., 1972: Echinodermi di Boka Kotorska (Bocche di Cattaro, Adriatico). Thalassia Salent. 6, 37-46.

CARUs, J.V., 1895: Prodromus faunae mediterraneae. Schweizerbart, Stuttgart, 524 pp.

Despalatović, M., Cvitković, I. \& Žuljević, A., 2017: Checklist of the echinoderm fauna of the Adriatic Sea. Zootaxa 4353(1), 101-116.

Dhora, Dh., 2010: Regjistër i specieve të faunës së Shqipërisë. Shkodër, Camaj-Pipa, 120 pp.

Donatı, V., 1750: Della Storia Naturale Marina dell'Adriatico. Francesco Storti, Venezia, 81 pp.

Fredj, G., 1974: Stockage et exploitation des données en écologie marine. Mém. Inst. oceanogr. Monaco 7, 1-88.

Frka, D. \& Mesić, J., 2003: Tajne Jadrana. 2. ed. Adamić, Rijeka, 195 pp.

García Raso, J.E., Luque A.A., Templado, J., Salas, C., Hergueta, E., Moreno, D. \& Calvo, M., 1992: Fauna y flora marinas del Parque natural de Cabo de Gata-Nijar. Universidad Autónoma de Madrid, 289 pp.

GAsco, Fr., 1876: Descrizione di alcuni Echinodermi nuovi o per la prima volta trovati nel Mediterraneo. Rend. R. Acad. Sci. Fis. e Mat. Napoli 15 (2) (not seen).

Hansson, H.G., 2001: Echinodermata. In: M. J. Costello, C. Emblow \& R. White (Eds), European register of marine species. Mus. natn. Hist. nat. Paris, Patrimoines naturels, 50, 336-351.

Heller, C., 1868: Die Zoophyten und Echinodermen des Adriatischen Meeres. II. Echinodermen. Verh. K.k. zool. bot. Ges. Wien, 47-91.

KAšćElAn, S., MANDiĆ S., RADOviĆ, I. \& KRPO-ĆETKOviĆ, J., 2009: An annotated checklist of Echinodermata of Montenegro (the south Adriatic Sea). Zootaxa 2275, 21-40.

Koehler, R., 1927: Les échinodermes des mers d'Europe. II. Doin, Paris, 339 pp.

Kolosváry, G. V., 1937: Die Echinodermen des Adriatischen Meeres. Festschr. Embrik Strand, Riga, $2,433-474$.

Kolosváry, G. V., 1938: Echinodermata iz Boke Kotorske. Godišnjak Oceanografskog Instituta Kraljevine Jugoslavije 1, Split, pp. 121-125. 
Kolosváry, G. V., 1940: Über die geographische Verbreitung einiger adriatischen Echinodermen. Folia Zool. Hydrob. 10 (2), 371-381.

LEGAC, M., 2012: Katalog zbirke Jadranskih i slatkovodnih školjkaša (Mollusca, Bivalvia) Prirodoslovnog muzeja Rijeka. The catalogue for the collection of Adriatic and fresh water bivalves (Mollusca, Bivalvia) in Natural History Museum Rijeka. Prirodoslovna biblioteka 17, 184 pp.

MarcuzzI, G., 1972: Le collezioni dell'ex Istituto di Biologia Marina di Rovigno conservate presso la Stazione Idrobiologica di Chioggia. Atti Mem. Acad. Patavina Sci. Lett. Arti 84 (2), 169-219.

Massé, H., 1994: 5. Biocénose Infralittorale et Circalittorale. In: D. Bellan-Santini, Lacase J.-C. \& Poizat, C. (Eds), Les biocénoses marines et littorales de Méditerranée. Synthèse, menaces et perspectives. Museum National d'Histoire Naturelle, Paris. Patrimoines Naturels, 19, 60-62.

Matarrese, A., 2010: Echinodermata. In: G. Relini (Ed.), Checklist della flora e fauna dei mari italiani (Parte 2). Biol. Mar. Mediterr. 17 (suppl. 1), 519-624.

Mortensen, T., 1951: A monograph of the Echinoidea. V (2). Spatangoida II. C. A. Reitzel, Copenhagen, $593 \mathrm{pp}$.

Olivi, G., 1792: Zoologia Adriatica, Bassano, 334 pp.

PAstorino, E. \& CANU, S., 1965: Osservazioni intorno alla fauna marina bentonica di Camogli e dintorni (Riviera ligure di levanto). Doriana 4 (159), 1-9.

PérÈs, J. M. \& GAMUlin-BridA, H., 1973: Biološka oceanografija. Školska knjiga, Zagreb, 493 pp.

PÉRÈs, J.M. \& Picard, J., 1964: Nouveau manuel de bionomie benthique de la Méditerranée. Rec. Trav. Sta. mar. Endoume 47 (Bull. 31), 3-137.

Strenger, A., 1970: Stamm: Echinodermata (Stachelhäuter). In: R. Riedl (Ed.), Fauna und Flora der Adria (2 Ed.), 491-518. P. Parey, Hamburg u. Berlin, 702 pp.

Tortonese, E., 1935: Contributo alla conoscenza degli echinodermi mediterranei. Annali Mus. civ. Stor. nat. Genova 57, 219-272.

Tortonese, E., 1956: Catalogo degli Echinodermi della collezione E. Tortonese. Ann. Mus. civ. St. nat. Genova 68, 177-233.

Tortonese, E., 1957: On the Echinoderm fauna of Haifa bay. Bull. Res. Council Israel 6B (3-4), 189-192.

ToRTONESE, E., 1961: Ehinodermi di Taranto (Mar Jonio). Thalassia Jonica 4, 190-194.

Tortonese, E., 1965: Echinodermata. Fauna d'Italia, 5. Calderini, Bologna, 419 pp.

ToRTONESE, E., 1977: Recenti acquisizioni e rettifiche intorno ai crinoidi, oloturioidi ed echinoidi del Mediterraneo, con particulare riguardo alla fauna italiana. Atti Soc. ital. Sci. nat. Mus. civ. Stor. nat. Milano 118 (3-4), 333-352.

Tortonese, E., 1984: Echinodermi del Museo di Storia Naturale di Verona (Collezione E. Tortonese). Mus. civ. Stor. nat. Verona, Ser. Cataloghi, 2: 1-73.

VASSEUR, E. \& CARLSEN, I., 1948: Sexual maturity of the sea-urchin Brissopsis lyrifera (Forbes) in the Gullmar fjord. Arkiv Zool. 41 A (16), 1-10.

Vidović Matvejev, A., 1978: Catalogue of the Adriatic echinoderms. Acta Adriat. 17 (15), 1-21.

Zavodnik, D., 1961: Seznam Jadranskih ehinodermov in njihova globinska razširjenost. Biol. vestn. Ljubljana, 8, 49-55.

Zavodnik, D., 1963: Pinna nobilis L. comme centre d'association. Rapp. p.v. Comm. int. Exp. sci. mer Médit. 17 (2), 273-275.

Zavodnik, D., 1971: Osvrt na poznavanje iregularnih ježinaca (Echinoidea, Irregularia) Jadranskog mora. 1. Jugoslavenski simpozij iz sistematike, Sarajevo, 10-14.11.1971. Zbornik referata, 215-219.

ZAvodNIK, D., 1992: Prilozi morskoj flori i fauni lošinjske otočne skupine. VII. Bodljikaši (Echinodermata). Otočki ljetopis Cres-Lošinj 8, 257-264.

ZavodNiK, D., 1996: Bodljikaši (Echinodermata) Murterskog mora s posebnim osvrtom na Kornatsko otočje. Simpozij 'Kornati. Prirodna podloga, zaštita, društveno i gospodarsko valoriziranje'; Murter, Tisno, Kornati, Šibenik, 2.-7.10.1995. Priopćenja. Ekol. Monogr. 7, 269-288.

Zavodnik, D., 2003: Marine fauna of Mljet National Park (Adriatic Sea, Croatia). 2. Echinodermata. Acta. Adriat. 44 (2), 105-160.

Zavodnik, D. \& Kovačić, M., 2000: Index oof marine fauna in Rijeka Bay (Adriatic Sea, Croatia). Nat. Croat. 9 (4), 297-379.

ZavodniK, D. \& Šimunović, A., 1997: Beskralješnjaci morskog dna Jadrana. IP 'Svjetlost', Sarajevo, 217 pp.

Zavodnik, D., Zavodnik N. \& IvešA, LJ., 2001: The 110th anniversary of the marine research at Rovinj (Adriatic Sea, Croatia). Reference collections. Nat. Croat. 10 (1), 53-60. 